\title{
Türkiye'deki İllerin Bankacılık Faaliyetleri Açısından Çok Değişkenli İstatistiksel Yöntemler ile İncelenmesi
} (Araştırma Makalesi)

\author{
Determination of Turkey Province with Multivariate Statistical Methods in \\ terms of Banking Activities
}

Doi: 10.29023/alanyaakademik.685945

Ceren YAMAN YILMAZ

Ö̆rr. Gör. Dr., Gazi Üniversitesi, cerenyaman@gazi.edu.tr

Orcid No: 0000-0002-6922-0664

Bu makaleye atıfta bulunmak için: Yaman Yılmaz, C. (2020). Türkiye'deki Illerin Bankacıllı Faaliyetleri Açısından Çok Değişkenli İstatistiksel Yöntemler ile İncelenmesi. Alanya Akademik Bakış, 4(2), Sayfa No. 471-493.

\begin{abstract}
Anahtar kelimeler:
Bankacılık, Çok

Değişkenli

Istatistiksel Analiz,

Temel Bileşenler

Analizi, Kümeleme

Analizi

Makale Geliş Tarihi:

19.02.2020

ÖZET

Bu çalışmanın amacl, bankacılık verilerinden oluşan değişkenleri kullanarak çok değişkenli istatistiksel analiz yöntemleri ile Türkiye'deki iller arasındaki benzerlik ve farklılıkları ortaya koymaktır. Bu bağlamda 2018 yılına ilişkin 10 farkl bankacılık göstergesi ile 81 il için analizler gerçekleştirilmiştir. Çalışmada ilk aşama olarak, çok değişkenli istatistiksel analiz yöntemlerinden temel bileşenler analizi (TBA) uygulanmış, sonrasinda hem ham veriler hem de TBA ile elde edilen bileşenler kullanılarak kümeleme analizi yapılmıştır. Her iki durumda elde edilen sonuçlar kıyaslanmıştır.
\end{abstract}

Kabul Tarihi:

02.05 .2020

Keywords:

Banking,

Multivariate

Statistics, Principal

Component Analysis,

Cluster Analysis

\begin{abstract}
The aim of this study to use variables of banking data to demonstrate the similarities and differences between multivariate statistical analysis methods and provinces in Turkey. In this context, analyses were carried out for 81 provinces with 10 different banking indicators for 2018. As the first stage in the study, principal components analysis (TBA) was applied from multivariate statistical analysis methods, and then clustering analysis was performed using both raw data and components obtained by TBA. The results obtained in both cases were compared.
\end{abstract}

\section{GİRIŞ}

Türkiye, gelişmekte olan ülkelerden biridir. $\mathrm{Bu}$ bağlamda topyekûn gelişmenin sağlanabilmesi için illerin gelişmesi önemlidir. İller hem yönetsel bir sistem hem de sosyoekonomik sistemlerdir. Bu bağlamda illerin, ülke alanını oluşturduklarından, planlı bir 
kalkınmanın temel hareket noktalarından biri olduğu kabul edilmektedir (Albayrak, 2005: 154).

Türkiye'de il ve ilçelerin gelişmişliklerinin incelenmesine ilişkin ilk çalışmalar Devlet Planlama Teşkilatı tarafından yapılmıştır. Kalkınma planlarının hazırlamasına ışık tutması amacıyla yapılan bu çalışmalarda sıklıkla çok değişkenli istatistiksel analiz yöntemlerine başvurulmuştur. Son olarak 2004 yılında yayınlanan söz konusu çalışmaların ardından araştırmacıların ilgi odağı olan bu araştırma konusu güncel veriler kullanılarak farklı başlıklar altında tekraren yapılmıştır.

Dinçer vd. (2003) çalışmasında gelişmişliğin tanımını, sosyal ve ekonomik göstergeler arasındaki etkileşimi ortaya koymak olarak vermiştir. Bu bağlamda 58 gösterge kullanan çalışma, bankacılık verilerine mali göstergeler başlığı altında yer vermiştir. İller arasındaki benzerlik ve farklılıkları ortaya koymayı veya sosyo-ekonomik gelişmişlik sıralaması yapmayı amaçlayan diğer araştırmalar incelendiğinde, bankacılık değişkenlerinin, birçoğu tarafından ekonomik gelişmişlik, mali göstergeler veya benzer isimli başlıklar altında ele alındığı görülmüştür. Dinçer vd. (2004)'teki "İlçelerin Sosyo-Ekonomik Gelişmişlik Sıralaması Araştırması" başlıklı çalışmalarında temel bileşenler analizi kullanmış ve analize dahil ettikleri 32 değişken arasına bankacılık göstergelerini de eklemişlerdir. Çok değiş̧kenli istatistiksel analizlerden faydalanarak illerin gelişmişlik sıralamasını yapan Albayrak, (2005), oluşturduğu gösterge kümesinde bankacıllk verilerine yer vermiştir. Şen vd. (2006) çalışmalarında faktör analizi ve temel bileşenler analizi kullanmış, aralarında bankacılık değişkenlerinin de bulunduğu 28 tane sosyo-ekonomik değişken ile gelişmişlik sıralaması elde etmiş̧lerdir. Kavasoğlu, (2007) çalışmasında, banka şube sayısı, fert başına düşen banka mevduatı, toplam mevduat içindeki pay, toplam krediler içindeki pay, kırsal nüfus başına düşen tarımsal krediler ile fert başına düşen sınai-ticari-turizm kredilerini kapsayan bankacılık verilerini kullanmıştır. Ersungur, vd, (2007) temel bileşenler analizinden yararlanarak yaptığı çalışmasında 10 adet değişken kullanmış ve bunlardan biri de bankacılık değişkeni olmuştur. Kalkınma Bakanlığı'nın 2013 yılında yayınladığı (SEGE 2011) ve pek çok araştırmaya yön veren "İllerin ve Bölgelerin Sosyo-Ekonomik Gelişmişlik Sıralaması" isimli çalışmasında temel bileşenler analizi kullanılmıştır. Sekiz başlık altında 61 göstergeye yer veren araştırma, bankacılık göstergelerini de analize dahil etmiştir. Çevik vd. (2014) yaptıkları çalışmada, Türkiye'de illerin gelişmişlik düzeyini temel bileşenler analizi ile incelemiştir. Çalışmada toplam 49 kriter kullanılmış, bunlardan 32 tanesini ekonomik değişkenler oluşturmuş ve bu başlık altında bankacılık verileri de yer bulmuştur. Orta Karadeniz Kalkınma Ajansı'nın 2014 tarihli ve "TR83 Bölgesi Sosyo-Ekonomik Gelişmişlik Endeksi" başlıklı araştırmasında (SEGE 2014), temel bileşenler analizinden yararlanılmış ve bankacılık verilerini de içeren 55 değişken kullanılmıştır. Kart vd., (2019) faktör analizi kullanarak yaptıkları çalışmalarında, 31 esas değişkene yer vermiş ve ekonomik değişkenler başlığı altında bankacılık değişkenlerinin de bulunduğu görülmüştür.

Kalkınmada öncelikli birimlerin tespiti, kamu kaynaklarının doğru aktarımı, özel sektör yatırımlarının yönlendirilmesi ve kontrolsüz göçün önüne geçebilmek amacıyla oluşturulması planlanan politikalara kaynak olması amaçlanan sosyo-ekonomik gelişmişlik çalışmalarına literatürde sıklıkla rastlamak mümkündür. $\mathrm{Bu}$ araştırmalarda çok sayıda değişkenin kullanımının yanı sıra, bir konuya ait değişkenlerin kullanıldığı çalışmalar da mevcuttur. Bu bağlamda; kümeleme analizinden faydalanarak illerin kültürel yapılarına ilişkin bir sınıflama yapan Çakmak vd. (2005) ve "Türkiye'deki İllerin Eğitim ve Sağlık Göstergelerine Göre 
Sınıflandırılması" başlıklı çalışmasında illerin sadece eğitim ve sağlık göstergeleri dikkate alınmış ve çok değişkenli istatistiksel analiz yöntemleri kullanan Öztürk vd. (2015) örnek gösterilebilir.

Ülkelerin kalkınmasında bankacılık sektörü çok kıymetli bir rol üstlenmektedir. Ekonomideki âtıl fonları, fona ihtiyacı olan birimlere aktarma fonksiyonu olan bankalar, bu fonksiyonu yerine getirirken, risk ve gelir arasında bir denge kurmak durumundadır. Söz konusu dengeyi kurmak ancak esnek bir yönetim sistemi ile mümkün olur. Bu sistemin ne kadar sağlıklı olduğu ve işlemesi ise bankaların faaliyet gösterdiği ekonomik ve finansal koşulların sağlığı ile yakından ilgilidir (Günal, 2001:1) Bu bağlamda illere ait bankacılık verilerinin, illerin gelişmişlik düzeyleri ile ilgili en güçlü bilgiyi sağlayacağı düşünesi ile çalışma salt bankacılık verilerinden elde edilen değişkenlerle yapılmış ve aşağıda verilen değişkenler seçilerek analize dâhil edilmiştir.

Çok değişkenli istatistiksel analizlerde değişken seçimi oldukça önemlidir. Bu sebeple mümkün olabilecek en çok sayıda değişken tercih edilmeli sonrasında ise kullanılacak analizlerin yapısı gereği söz konusu değişkenler azaltılmalıdır. Bu çalışmada bankacılık sektörüne ait 10 temel gösterge kullanılmıştır. Göstergelere ait tüm veriler Türkiye Bankalar Birliği'nden 2018 yılı için elde edilmiştir. Analizlerde SPSS v.25 paket programı kullanılmıştır.

1. Şube sayısı

2. Faaliyet gösteren banka sayısı

3. Toplam kredi (milyon TL)

4. Toplam mevduat (milyon TL)

5. ATM sayıs1

6. POS sayis1

7. Üye işyeri sayısı

8. Çalışan sayısı

9. ATM başına kişi sayısı

10. Şube başına kişi sayısı

\section{METODOLOJI}

Bu bölümde, araştırmada kullanılan çok değişkenli istatistiksel analiz yöntemlerinden, temel bileşenler analizi ve kümeleme analizi hakkında teorik bilgi verilmiştir.

\subsection{Temel Bileşenler Analizi}

Temel bileşenler analizi ilk kez 1900'lerin başında Karl Pearson tarafından tanıtılmıştır. Yöntemin şekilsel yaklaşımı, Hotelling (1933) ve Rao (1964)'ten ileri gelmektedir. Temel bileşenler analizinde, birbiriyle ilişkili bir dizi $\mathrm{p}$ değişkeni, temel bileşenler olarak adlandırılan korelâsyonsuz varsayımsal yapılara dönüştürülür. Temel bileşenler, değişkenler arasındaki mevcut bağımlılıkları keşfetmek, yorumlamak ve bireyler arasında var olabilecek ilişkileri incelemek için kullanılmaktadır. Temel bileşenler, tahminleri istikrara kavuşturmak, çok değişkenli normalliği değerlendirmek ve aykırı değerleri tespit etmek için kullanılabilir (Timm, 2002: 469).

Farrar ve Glauber, Haitovsky, Massy, Meyer ve Kraft ekonometrik problemlerde bu tekniği kullanmışlardır. Rao araştırmalarında, boyut ve şekil faktörlerinin belirlenmesinde temel bileşenler analizi (TBA) kullanmanın yararlı olacağının örneklerini vermektedir. Girshick 
(1939) ve Anderson (1958), temel bileşenlerin dağılım ve örneklem özelliklerini ele almışlar ve geliştirmişlerdir. Morrison (1967), temel bileşenlerin geometrik yorumlanmasına ve diğer özelliklerine değinmiştir. Bilgisayar kullanımının gelişmesinden sonra Cooley ve Lohnes (1971), temel bileşenlerin bir uygulama ile bilgisayara uyarlanmasını ve pratikte yorumlanmasını göstermiştir. Ayrıca, temel bileşenler analizinin kuramsal yapısının temelini oluşturan yaklaşımı, genelleştirilmiş en küçük kareler yöntemi ve özdeğerleri kullanarak göstermiştir (Abdel-Aziz, 1993: 2). Konunun kapsamlı bir tartışması Jolliffe (1986), Jackson (1991) ve Basilevsky (1994) tarafından sağlanmıştır (Timm, 2002: 469).

Temel bileşenler analizinin kullanımının pratik amaçları; seçilen bir kümedeki değişkenler arasındaki korelâsyonun incelenmesi, ölçülen değişkenliğin temel boyutlarının en küçük anlamlı boyutlara indirgenmesi, nispeten az bilgi içeren değişkenlerin dışlanması, uzaydaki n-boyutlu bireylerin gruplandırılması ve bireylerin daha önce ayrılmış olan gruplara atanması şeklinde özetlenebilir. Analiz, bahsi geçen problemler için tek bir çözüm verir ve en az sayıda varsayımla bilgisayar vasitasıyla uygulaması kolaydır (Jeffers, 1967:235).

$\mathrm{n}$ tane her bir birey için gözlemlenen $\mathrm{X}_{1}, \mathrm{X}_{2}, \ldots . ., \mathrm{X}_{\mathrm{p}}$ gibi $\mathrm{p}$ tane değişken olduğu ve $\mathrm{i}$. bireyin gözlem vektörünün $\left.\mathrm{X}^{(\mathrm{i}}\right)=\left(\mathrm{X}_{\mathrm{i} 1}, \mathrm{X}_{\mathrm{i} 2}, \ldots, \mathrm{X}_{\mathrm{ip}}\right)$ biçiminde ifade edildiği varsayılsın. Temel bileşenler analizi, $X_{1}, X_{2}, \ldots, X_{p}$ değişkenlerini doğrusal olarak yeni $Y_{1}, Y_{2}, \ldots, Y_{m}$ değişkenlerine dönüştürür. Dolayısıyla gözlem verilerine karşılık gelen temel bileşen skorları $\mathrm{Y}^{(\mathrm{i})}=\left(\mathrm{Y}_{\mathrm{i} 1}, \mathrm{Y}_{\mathrm{i} 2}, \ldots, \mathrm{Y}_{\mathrm{ip}}\right)$ şeklinde olur (Krzanowski, 1987:22).

TBA, bir dizi ilişkili değişkeni yeni bir ilişkisiz değişkenler kümesine dönüştürür. $\mathrm{Bu}$ nedenle, orijinal değişkenlerin arasında korelasyon yoksa, temel bileşenler analizi uygulamanın bir anlamı olmadığını vurgulamakta fayda vardır. (Chatfield vd. 1980:57). TBA ile, başlangıçta bir dizi $\mathrm{p}$ tane bileşen ile açıklanan problem, en uygun sayıda seçilen $\mathrm{m}$ tane temel bileşen ile açıklanmaya çalışılır. m değişkenli bu alt küme, p orijinal değişkendeki genel yapıya mümkün olduğunca en yakın olarak yeniden elde edilmiş değişkenleri içeren bir alt kümedir. Söz konusu ideal alt kümeyi tespit etmek için, orijinal değişkenler arasında, birbirleri ile yüksek korelasyonlu değişkenlerin olup olmadığı kontrol edilir. Birbirleri ile yüksek korelasyonlu değişkenler arasında yakın bir doğrusal ilişki bulunmaktadır (Özgür, 2003:5).

Temel bileşenler analizinin özel bir amacı, gözlenen değişkenler arasındaki korelasyon yapısını, fazla sayıdaki değişkeni daha az sayıdaki yapılar şeklinde indirgeyebilmek için özetlemektir. Temel bileşenler analizi çok sayıdaki değişkeni birkaç yapı biçiminde ifade etmekte oldukça kullanışlı yöntemlerdir. Matematiksel olarak temel bileşenler analizi, gözlenen değişkenlerin her bir doğrusal kombinasyonunu ifade edecek şekilde bir yapıyı tanımlar. Bu yapılar gözlenen korelasyon matrisindeki korelasyon yapısını özetler ve gözlenen korelasyon matrisinin yeniden oluşturulmasında kullanılabilir. Bileşen sayısı genellikle gözlenen değişken sayısından çok daha az olduğu için güvenilir sonuçlar verecektir.

Temel bileşenler analizinin aşamaları:

1) Değişken kümelerini seçme ve ölçme,

2) Korelâsyon matrislerinin oluşturulması,

3) Korelâsyon matrislerinden bileşen kümelerinin çıkarılması, 
4) Bileşen sayısının belirlenmesi,

5) Sonuçların yorumlanması şeklindedir.

$\mathrm{Bu}$ adımların birçoğu istatistiksel açıdan gerekli olmasına rağmen analizin önemli bir testi yorumlanabilir olup olmamasıdır. Yorumlama ve bileşenlere isim verme, gözlenen değişkenlerin özel kombinasyonlarının her bir bileşenle yüksek bir korelâsyona sahip olup olmadıklarına bağlıdır. Çok sayıdaki gözlenen değişkenin herhangi bir bileşenle yüksek korelasyona sahip olması ve bu değişkenlerin diğer bileşenlerle önemli bir korelasyon göstermesi, o bileşenin kolaylıkla yorumlanabilmesi anlamına gelir (Yaman Yı1maz vd., 2016: 194).

\subsection{Kümeleme Analizi}

Kümeleme analizinin genel amacı, gruplanmamış verileri benzerliklerine göre sınıflandırmak (gruplamak) ve araştırmacıya uygun, işe yarar özetleyici bilgiler elde etmede yardımcı olmaktır.

Küme, birbirine yakın (benzer) bireylerin çok boyutlu uzayda oluşturdukları bulutlar benzetmesi ile ifade edilebilir. Bu ifadeden de anlaşılacağı gibi küme kavramı, benzerlik (similarity) ve uzaklık (distance) gibi kavramları çă̆rıştırmaktadır (Tatlıdil, 2002: 330).

Kümeleme analizinin aşamaları aşağıdaki gibi sıralanabilir:

1) Veri girişi,

2) Uzaklıklar matrisinin elde edilmesi,

3) Kümeleme tekniğinin seçilmesi ve uygulanması,

4) Sonuçların duyarlılığının ve anlamlılığının sorgulanması,

5) Sonuçların değerlendirilmesi

Kümeleme analizinde veri girişinin ardından, Minkowski uzaklığı, ManhattanCity-Block uzaklığı, Öklit (Euclidean) uzaklığı, Mahalonobis uzaklığı, Hotelling T² uzaklığı ve Canberra uzaklığından biri tercih edilerek uzaklık matrisi elde edilir. Sonrasında hiyerarşik ve hiyerarşik olmayan yöntemler olmak üzere iki başlık altında toplanan yöntemlerden biri seçilerek uygulanır. Amaç küme içi varyansları en küçük, kümeler arası varyansları en büyük yapmaktır.

Hiyerarşik kümeleme yöntemleri, işleyişin kolay anlaşılabilmesi açısından ağaç diyagramı örneğinden yaralanmaktadır. Öyle ki, kümeleme sürecinin başlangıcında her birey bir kümedir (ağacın dallarl), süreç sonunda tüm bireyler bir kümede toplanır (ăgacın gövdesi) (Tatlidil, 2002: 334).

Hiyerarşik kümeleme yöntemlerinde gözlemler arasındaki uzaklık değerleri kullanılmaktadır. Başlangıçta, her bir gözlem ayrı bir küme olarak ele alınırken algoritma tamamlandığında tüm bireyler tek bir kümede toplanmış olur (Özgür, 2003: 101).

Uygulama öncesi hiyerarşik kümeleme metotları ile kaç küme oluşacağı bilinmemektedir. Birbirine en çok benzeyen birimler, başlangıçta öngörülen kriterlere göre (bu çalışma için kareli Euclidian uzaklık) aynı kümenin içinde yer alır. Kümeleme işlemi, verideki son birim kendine en fazla benzeyen kümeye atanana kadar devam eder. S1k kullanılan yedi hiyerarşik 
kümeleme metodu; tek bağlantı metodu, tam bağlantı metodu, tartısız eşlenik grup ortalaması metodu, tartılı eşlenik grup ortalaması metodu, tartısız eşlenik grup merkezi metodu, tartılı eşlenik grup merkezi (medyan) metodu ve Ward metodudur (Yaylalı, Oktay, Akan, 2006: 313).

Hiyerarşik kümeleme yöntemlerinde en önemli konulardan birisi de küme sayısının belirlenmesidir. Bu aşamamda en çok başvurulan yöntem aşağıdaki gibidir. Küçük örneklerde işe yarayan bu yöntem, büyük örneklerde sağlıklı sonuçlar vermemektedir.

$k=(n / 2)^{1 / 2}$

Hiyerarşik olmayan kümeleme yöntemleri, küme sayısı hakkında ön bilgi olması ve araştırmacının küme sayısına karar vermiş olması durumunda tercih edilmektedir. Bunun yanı sıra hiyerarşik kümeleme yöntemlerine göre daha az karmaşık olması ve daha az zaman alması uygulamalarda sıklıkla yer bulmasında etkilidir. Araştırmacılar tarafindan en çok tercih edilen yöntem k-ortalamalar tekniğidir.

Küme sayısının tespitinde bazı yöntemlerden yararlanılsa da belirleme aşamasında araştırmacının bilgi düzeyi, mesleki tecrübesi ve sonuçların anlamlı olup olmaması küme sayısını etkileyen faktörlerdendir. Kümeleme analizi sonuçları, uzaklık ölçüleri ve seçilen yönteme bağlı olarak farklı çıkabilmektedir. Bu farkı elimine etmek için temel bileşenler analizinden faydalanılmaktadır. Böylelikle, çok sayıda değişken olması durumunda değişken sayısı azaltılarak daha doğru sonuçlar elde edilebilir (Özgür,2003: 109).

\section{UYGULAMA}

Uygulama kapsamında, Türkiye istatistiki bölge birimleri sınıflandırması (İBBS) düzey 3'e ait 2018 yılı bankacılık verileri kullanılarak temel bileşenler analizi yapılmış, akabinde ham verilere kümeleme analizi uygulanmıştır. Son aşama olarak temel bileşenler analizi sonuçlarından elde edilen verilere kümeleme analizi uygulanarak sonuçlar karşılaştırılmıştır. Analizlerde SPSS v.25 paket programı kullanılmış, sonuçlar ayrıntılı biçimde sunulmuştur.

\subsection{Temel Bileşenler Analizi Sonuçları}

Değişkenler arasındaki ilişkilerin önemli olup olmadığını ve verinin temel bileşenler analizine elverişli olup olmadığını ortaya koymak için, Kaiser-Meye-Olkin (KMO) ve Bartlett Küresellik testi uygulanmıştır. Tablo 1 incelendiğinde KMO testi sonucunun \%81.6 (0.816) olduğu görülmektedir. 81.6 değeri 0.80 değerinden büyük olduğu için veri setinin analiz için uygun olduğunu söylenebilir. Bartlett testi sonucu incelendiğinde $\mathrm{p}(\mathrm{sig})$ değeri $\alpha=0.05$ değerinden küçük olduğu için $\mathrm{H}_{0}$ hipotezi reddedilir. Bu demektir ki, değişkenler arasında yüksek korelasyon vardır ve temel bileşenler analizi yapılabilir. 
ALANYA AKADEMIK BAKIŞ DERGİSI 4/2 (2020)

Tablo 1. KMO ve Bartlett Testi Sonuçları

\begin{tabular}{|l|l|l|}
\hline \multicolumn{2}{|l|}{ Kaiser-Meyer-Olkin } & .816 \\
\hline \multirow{3}{*}{ Bartlett testi } & Yaklaşık Ki-Kare & 3073.280 \\
\cline { 2 - 3 } & sd & 45 \\
\cline { 2 - 3 } & p (sig.) değeri & .000 \\
\hline
\end{tabular}

Tablo 2'ye bakıldığında değişkenlere ait ortak varyans (communality) değerlerinin oldukça yüksek olduğu ve tamamının 0.50 'den büyük olduğu görülmektedir. Bu aşamada en yüksek ortak varyansa sahip olan değişkenin üye işyeri sayısı ve çalışan sayısı olduğu görülmüştür. 
YAMAN YILMAZ

Tablo 2. Ortak Varyans Tablosu

\begin{tabular}{|l|l|l|}
\hline & Başlangıç & Döndürülmüş \\
\hline Şube sayısı & 1.000 & .996 \\
\hline Banka sayısı & 1.000 & .742 \\
\hline Toplam kredi & 1.000 & .984 \\
\hline Toplam mevduat & 1.000 & .974 \\
\hline ATM sayısı & 1.000 & .992 \\
\hline POS sayısı & 1.000 & .997 \\
\hline Üye işyeri sayısı & 1.000 & .997 \\
\hline Çalışan sayısı & 1.000 & .977 \\
\hline ATM başına kişi sayısı & 1.000 & .968 \\
\hline Şube başına kişi sayısı & 1.000 & .954 \\
\hline
\end{tabular}

Tablo 3'te özdeğeri birden büyük iki tane temel bileşen olduğu görülmektedir. Birinci temel bileşen tek başına toplam varyansın \%77.6'sını, ikinci temel bileşen ise \%18.5'ini açıklamaktadır. Her iki bileşen birlikte toplam varyansın \%95.8'ini açıklamaktadır. Bu oldukça tatmin edici bir sonuçtur.

Tablo 3. Özdeğere Bağlı Temel Bileșen Sayısı ve Açıklanan Toplam Varyans Yüzdesi

\begin{tabular}{|l|l|l|l|l|l|l|}
\hline \multirow{4}{*}{ Bileşen } & \multicolumn{3}{|l|}{ Başlangıç özdeğerleri } & \multicolumn{3}{l|}{ Döndürülmüs kareli yükler toplamı } \\
\cline { 2 - 7 } & Toplam & Varyans \%'si & Kümülatif \% & Toplam & Varyans \%'si & Kümülatif \% \\
\hline 1 & 7.760 & 77.605 & 77.605 & 7.760 & 77.605 & 77.605 \\
\hline 2 & 1.821 & 18.214 & 95.819 & 1.821 & 18.214 & 95.819 \\
\hline 3 & .318 & 3.183 & 99.001 & & & \\
\hline 4 & .063 & .635 & 99.636 & & & \\
\hline 5 & .023 & .234 & 99.870 & & & \\
\hline 6 & .009 & .087 & 99.957 & & & \\
\hline
\end{tabular}




\begin{tabular}{|l|l|l|l|l|l|l|}
\hline 7 & .003 & .027 & 99.984 & & & \\
\hline 8 & .001 & .010 & 99.994 & & & \\
\hline 9 & .001 & .006 & 100.000 & & & \\
\hline 10 & $\begin{array}{l}2,758 \mathrm{E}- \\
5\end{array}$ & .000 & 100.000 & & & \\
\hline
\end{tabular}

Tablo 4'te verilen bileşen matrisi incelendiğinde, şube sayısı, banka sayısı, toplam kredi, toplam mevduat, ATM sayısı, POS sayısı, üye işyeri sayısı ve çalışan sayısının birinci temel bileşende, ATM başına kişi sayısı ve şube başına kişi sayısının ise ikinci temel bileşende yer aldığ 1 görülmüştür.

Tablo 4. Bileșen Matrisi

\begin{tabular}{|l|l|l|}
\hline \multicolumn{2}{|l|}{} & \multicolumn{2}{l}{ Bileşen } \\
\cline { 2 - 3 } & 1 & \multicolumn{2}{l|}{} \\
\hline Şube sayısı & .995 & .079 \\
\hline Banka sayısı & .849 & -.144 \\
\hline Toplam kredi & .983 & .132 \\
\hline Toplam mevduat & .977 & .140 \\
\hline ATM sayısı & .994 & .060 \\
\hline POS sayısı & .995 & .091 \\
\hline Üye işyeri sayısı & .995 & .086 \\
\hline Çalışan sayısı & .980 & .134 \\
\hline ATM başına kişi sayısı & -.322 & .930 \\
\hline Şube başına kişi sayısı & -.314 & .925 \\
\hline
\end{tabular}

Analiz öncesinde 10 göstergeye sahipken analiz sonucunda toplam varyansın \%96.1'ini açıklayan 2 temel bileşen elde edilmiştir.

\subsection{Kümeleme Analizi Sonuçları}

Araştırmanın bu aşamasında, uzaklık matrisinin belirlenmesinde kareli öklid uzaklığı (squared euclidian distance), illerin kümelendirilmesinde ise, hiyerarşik kümeleme 
yöntemlerinden tek bağlantı tekniği, tam bağlantı tekniği ve Ward tekniği; hiyerarşik olmayan kümeleme yöntemlerinden de sadece k-ortalama tekniği kullanılmıştır. Ayrıca k-ortalama tekniğinde, çeşitli küme sayılarında değişkenlerin önem düzeyleri incelenmiştir.

\subsubsection{Ham Verilere Uygulanan Kümeleme Analizi Sonuçları}

\subsubsection{Tek Bağlantı Tekniği Analiz Sonuçları}

Şekil 1'de verilen dendogram incelendiğinde, İstanbul ilinin tek başına bir küme oluşturduğu, diğer 80 ilin ise birlikte diğer kümeyi oluşturdukları gözlenmektedir. Bankacılık sektörüne ilişkin seçilen değişkenler bakımından İstanbul ili diğer tüm iller de açık ara farklıdır.

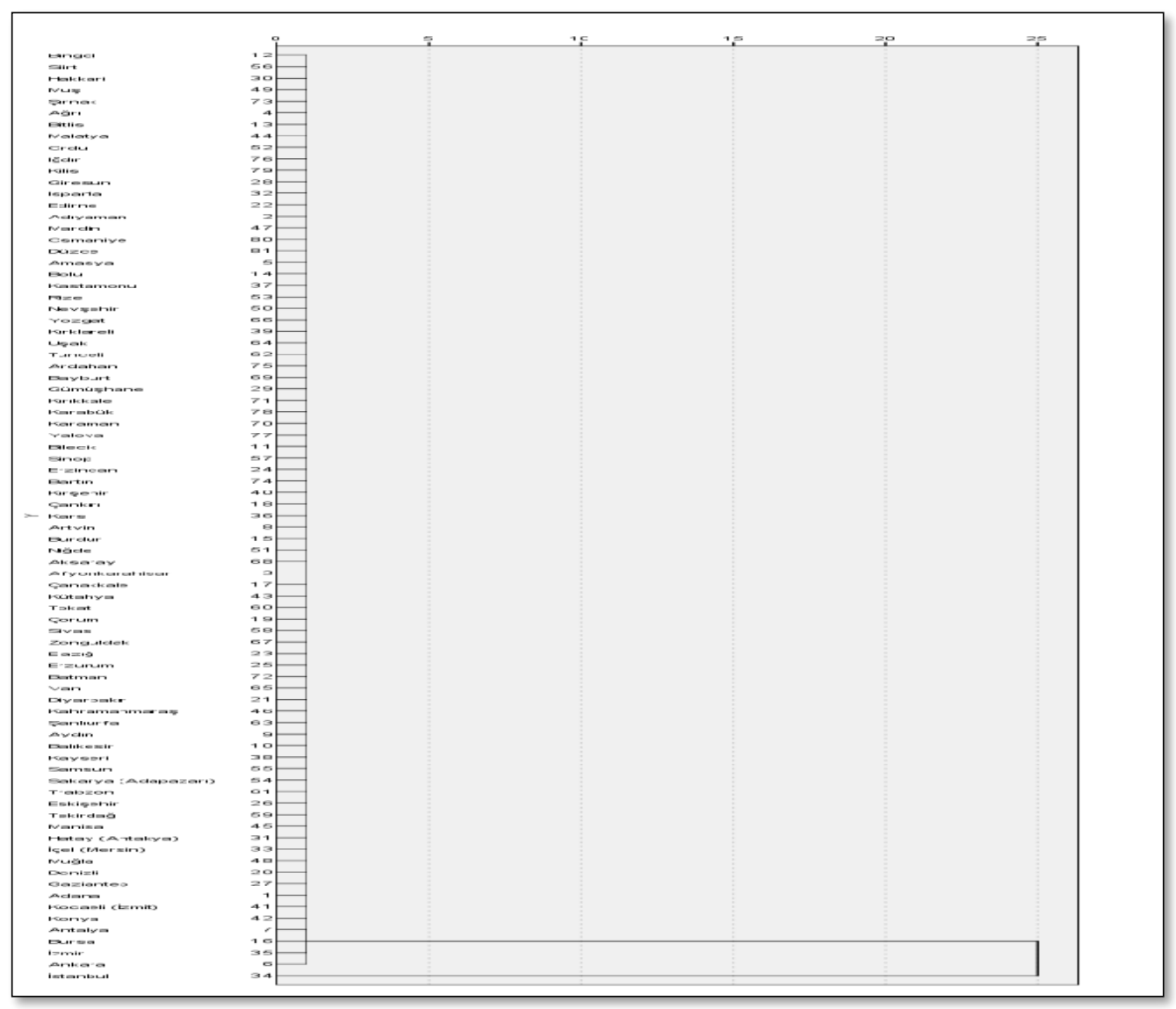

Şekil 1. Tek bağlantı tekniğine ait dendogram 


\subsubsection{Tam bağlantı tekniği analiz sonuçları}

Tam bağlantı tekniğine ilişkin dendogramın verildiği Şekil 2'de, ilk aşamada Ankara ve İstanbul dışındaki 79 ilin kümelendiği, ikinci aşamada bu kalabalık küme ile Ankara ilinin birleştiği ve en son aşamada İstanbul'un birleştiği görülmektedir.

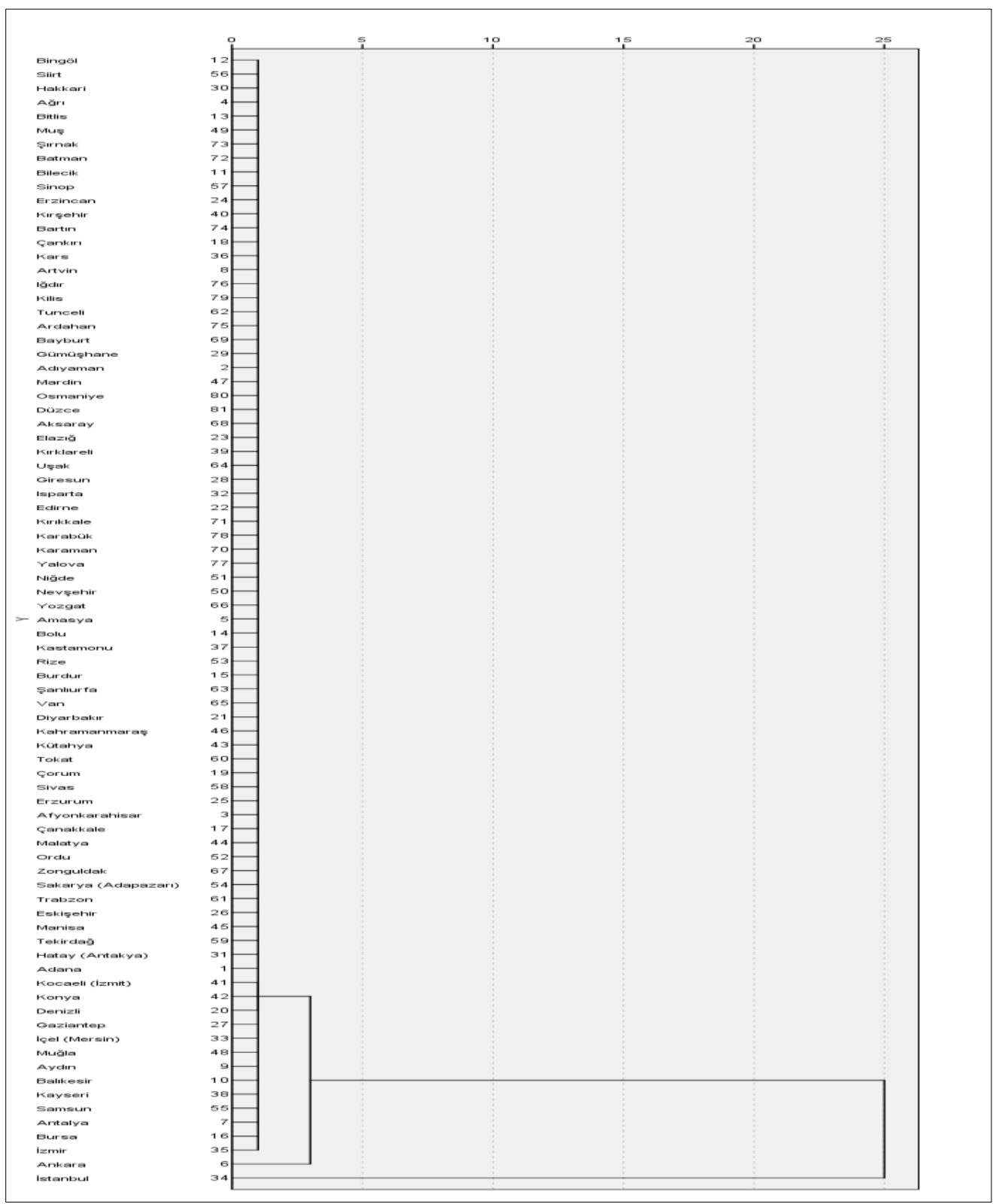

Şekil 2. Tam bağlantı tekniğine ait dendogram 


\subsubsection{Ward tekniği analiz sonuçları}

Şekil 3, Ward tekniğine göre Türkiye'deki illerin bankacılık verileri ışığında kümelenmesini göstermektedir. Buna göre, ilk olarak Antalya, Bursa, İzmir, Ankara illeri kendi arasında ve Muğla, İçel (Mersin), Samsun, Kayseri, Balıkesir, Aydın, Gaziantep, Denizli, Hatay (Antakya), Tekirdağ, Manisa, Eskişehir, Trabzon, Sakarya (Adapazarı), Konya, Kocaeli (İzmit), Adana, Van, Şanlıurfa, Kahramanmaraş, Diyarbakır, Erzurum, Ordu, Malatya, Zonguldak, Çanakkale, Afyonkarahisar, Elazı̆̆, Sivas, Çorum, Tokat, Kütahya, Edirne, Isparta, Giresun, Uşak, Kırklareli, Rize, Kastamonu, Bolu, Amasya, Yozgat, Nevşehir, Niğde, Aksaray, Düzce, Osmaniye, Mardin, Adıyaman, Artvin, Çankırı, Erzincan, Sinop, Bilecik, Kars, Bartın, Kırşehir, Burdur, Yalova, Karaman, Karabük, Kırıkkale, Gümüşhane, Bayburt, Ardahan, Tunceli, Kilis, Iğdır, Batman, Şırnak, Muş, Bitlis, Ağrı, Hakkâri, Siirt, Bingöl illeri kendi arasında kümelenmiştir. Sonrasında bu iki küme birleşmiştir. Son aşamada ise, İstanbul ili bu yeni küme ile birleşmiştir.

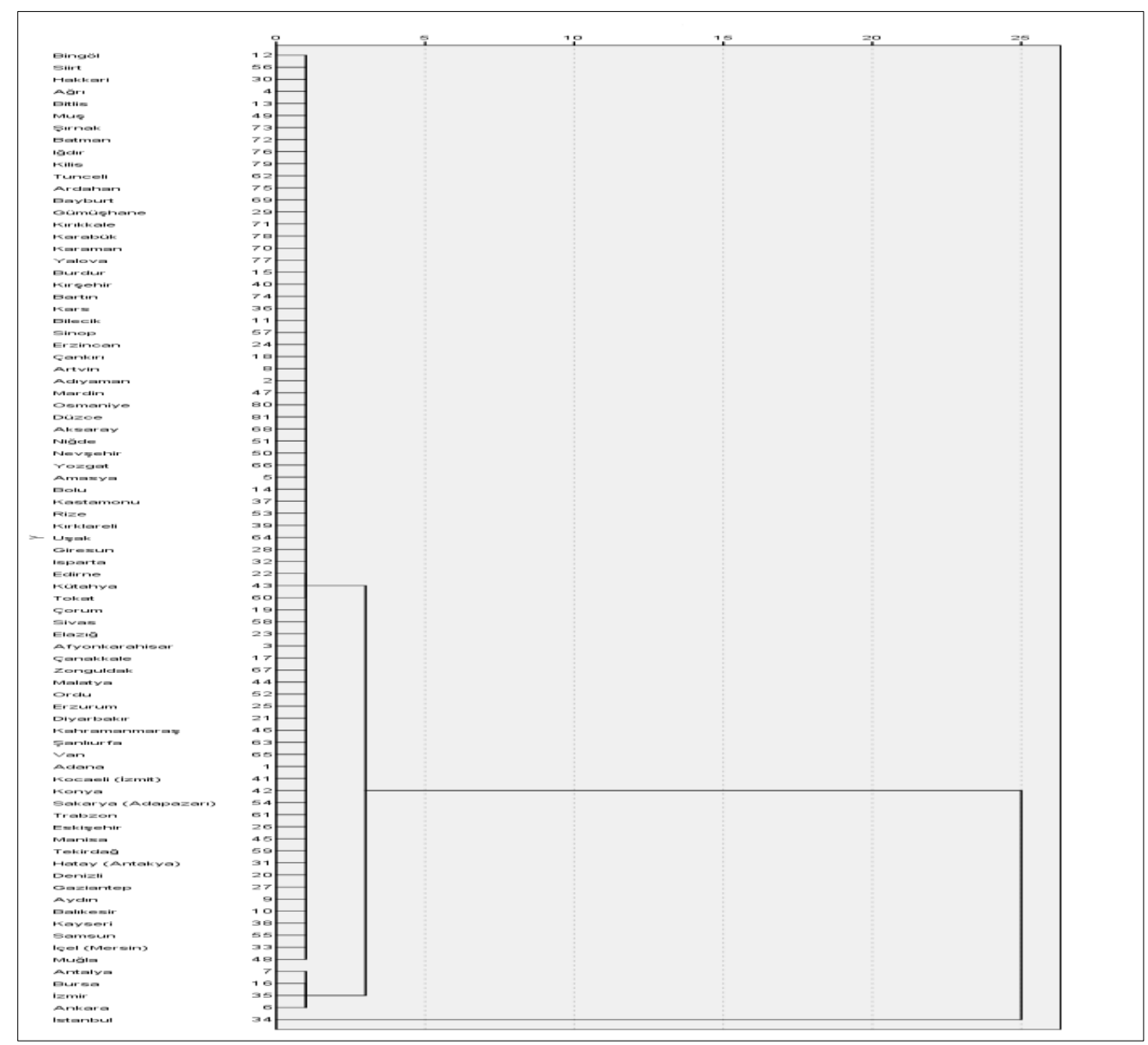

Şekil 3. Ward tekniğine ait dendogram 


\subsubsection{K-ortalamalar tekniği analiz sonuçları}

Söz konusu tekniği uygularken, hiyerarşik kümeleme yöntemleri ile elde edilen küme sayıları temel alınarak, küme sayısı önce 2 sonrasında ise 3 alınarak analiz gerçekleştirilmiş sonuçlar aşağıda özetlenmiştir.

Küme sayısı 2 olarak tercih edildiğinde elde edilen sonuçlar aşağı Tablo 5'te verilmiştir.

Tablo 5. Küme üyeliği

\begin{tabular}{|l|l|l|}
\hline $\begin{array}{l}\text { Küme } \\
\text { no }\end{array}$ & Küme elemanları & $\begin{array}{l}\text { Kümelerdeki } \\
\text { birim sayısı }\end{array}$ \\
\hline 1 & İstanbul & 1 \\
\hline 2 & $\begin{array}{l}\text { Adana, Diyarbakır, Konya, Tunceli, Adıyaman, Edirne, Kütahya, } \\
\text { Şanlıurfa, Afyonkarahisar, Elazığ, Malatya, Uşak, Ağrı, Erzincan, } \\
\text { Manisa, Van, Amasya, Erzurum, Kahramanmaraş, Yozgat, Ankara, }\end{array}$ \\
$\begin{array}{l}\text { Eskişehir, Mardin, Zonguldak, Antalya, Gaziantep, Muğla, } \\
\text { Aksaray, Artvin, Giresun, Muş, Bayburt, Aydın, Gümüşhane, } \\
\text { Nevşehir, Karaman, Balıesir, Hakkâri, Niğde, Kırıkkale, Bilecik, } \\
\text { Hatay (Antakya), Ordu, Batman, Bingöl, Isparta, Rize, Şırnak, } \\
\text { Bitlis, İçel (Mersin), Sakarya (Adapazarı), Bartın, Bolu, İzmir, } \\
\text { Samsun, Ardahan, Burdur, Kars, Siirt, Iğdır, Bursa, Kastamonu, } \\
\text { Sinop, Yalova, Çanakkale, Kayseri, Sivas, Karabük, Çankırı, } \\
\text { Kirklareli, Tekirdağ, Kilis, Çorum, Kırşehir, Tokat, Osmaniye, } \\
\text { Denizli, Kocaeli (İzmit), Trabzon, Düzce }\end{array}$ \\
\hline
\end{tabular}

Tablo 5 incelendiğinde, 2 kümeye ayrılan illerin hangi kümede bulundukları görülmektedir. İstanbul ili tek başına bir küme oluştururken, diğer 80 il diğer bir kümede yer almıştır. Tek başına bir kümeyi oluşturan İstanbul ili, hem ekonomik hacim hem de birçok açıdan tartışmasız Türkiye'nin en büyük ilidir. Çalışmaya dâhil edilen değişkenlerin sayısal büyüklükleri incelendiğinde ortaya çıkan sonuç şaşırtıcı değildir.

Tablo 6'da verilen Anova sonuçları incelendiğinde, şube başına kişi sayısı ve ATM başına kişi sayısı değişkenleri dışında diğer değişkenlerin p (sig) değerlerinin $\alpha=0.05$ 'ten küçük olduğu görülmüştür. Buna göre, söz konusu değişkenlerin önemsiz olduğu sonucuna varilabilir.

Tablo 6. ANOVA sonuçları

\begin{tabular}{|l|l|l|l|l|l|}
\hline & F değeri & $\mathrm{p}$ & & F değeri & $\mathrm{p}$ \\
\hline Şube sayısı & 335.616 & .000 & Çalışan sayısı & 971.426 & .000 \\
\hline ATM sayısı & 297.470 & .000 & $\begin{array}{l}\text { ATM başına kişi } \\
\text { sayısı }\end{array}$ & 1.136 & .290 \\
\hline POS sayısı & 452.755 & .000 & Şube başına kişi sayısı & 1.329 & .252 \\
\hline
\end{tabular}


YAMAN YILMAZ

\begin{tabular}{|l|l|l|l|l|l|}
\hline Üye işyeri sayısı & 443.842 & .000 & Toplam mevduat & 871.374 & .000 \\
\hline Banka sayısı & 46.635 & .000 & Toplam kredi & 625.804 & .000 \\
\hline
\end{tabular}

Küme sayısı 3 olarak tercih edildiğinde elde edilen sonuçlar aşağı Tablo 7'de verilmiştir.

Tablo 7. Küme üyeliği

\begin{tabular}{|l|l|l|}
\hline $\begin{array}{l}\text { Küme } \\
\text { no }\end{array}$ & Küme elemanları & $\begin{array}{l}\text { Kümelerdeki } \\
\text { birim sayısı }\end{array}$ \\
\hline 1 & İstanbul & 1 \\
\hline 2 & $\begin{array}{l}\text { Adana, Diyarbakır, Konya, Tunceli, Adiyaman, Edirne, Kütahya, } \\
\text { Şanlıurfa, Afyonkarahisar, Elazığ, Malatya, Uşak, Ağrl, Erzincan, } \\
\text { Manisa, Van, Amasya, Erzurum, Kahramanmaraş, Yozgat, } \\
\text { Eskişehir, Mardin, Zonguldak, Antalya, Gaziantep, Muğgla, } \\
\text { Aksaray, Artvin, Giresun, Muş, Bayburt, Aydın, Gümüşane, } \\
\text { Nevşehir, Karaman, Balıkesir, Hakkâri, Niğde, Kırıkale, Bilecik, } \\
\begin{array}{l}\text { Hatay (Antakya), Ordu, Batman, Bingöl, Isparta, Rize, Şırnak, } \\
\text { Bitlis, İçel (Mersin), Sakarya (Adapazarı), Bartın, Bolu, Samsun, } \\
\text { Ardahan, Burdur, Kars, Siirt, Iğdır, Bursa, Kastamonu, Sinop, } \\
\text { Yalova, Çanakkale, Kayseri, Sivas, Karabük, Çankırı, Kırklareli, } \\
\text { Tekirdağ, Kilis, Çorum, Kirşehir, Tokat, Osmaniye, Denizli, } \\
\text { Kocaeli (İzmit), Trabzon, Düzce }\end{array}\end{array}$ \\
\hline 3 & \begin{tabular}{l} 
Ankara, İzmir \\
\hline
\end{tabular} & 2 \\
\hline
\end{tabular}

Tablo 7, 3 kümeye ayrılan illerin hangi kümeye atandıklarını betimlemektedir. Buna göre, İstanbul ili tek başına birinci kümeyi, Ankara ve İzmir birlikte üçüncü kümeyi ve diğer 78 il ise ikinci kümeyi oluşturmaktadır. Küme sayısı artmasına rağmen İstanbul ilinin tek başına bir küme oluşturması beklenen bir durumdur.

Tablo 8'deki ANOVA sonuçlarına göre, iki küme sayısı ile yapılan k-ortalamalar tekniği sonuçları ile benzer şekilde şube başına kişi sayısı ve ATM başına kişi sayısı değişkenleri dışında diğer değişkenlerin $\mathrm{p}$ (sig) değerlerinin $\alpha=0.05$ ’ten küçük olduğu görülmüştür. 
Tablo 8. ANOVA sonuçları

\begin{tabular}{|l|l|l|l|l|l|}
\hline & F değeri & p değeri & & F değeri & p değeri \\
\hline Şube sayısı & 659.890 & .000 & Çalışan sayısı & 1377.522 & .000 \\
\hline ATM sayısı & 504.566 & .000 & ATM başına kişi & 1.701 & .189 \\
\hline sayısı & .000 & Şube başına kişi sayısı & 1.906 & .156 \\
\hline Üye işyeri sayısı & 678.513 & .000 & Toplam mevduat & 1960.202 & .000 \\
\hline Banka sayısı & 42.818 & .000 & Toplam kredi & 1098.790 & .000 \\
\hline
\end{tabular}

3.2.2. Temel bileşenler analizinden elde edilen 2 bileşen ile gerçekleştirilen kümeleme analizi sonuçları

\subsubsection{Tek bağlantı tekniği analiz sonuçları}

Şekil 4'teki dendogram incelendiğinde, İstanbul ilinin tek başına bir küme oluşturduğu, diğer 80 ilin ise birlikte diğer kümeyi oluşturdukları gözlenmektedir. 


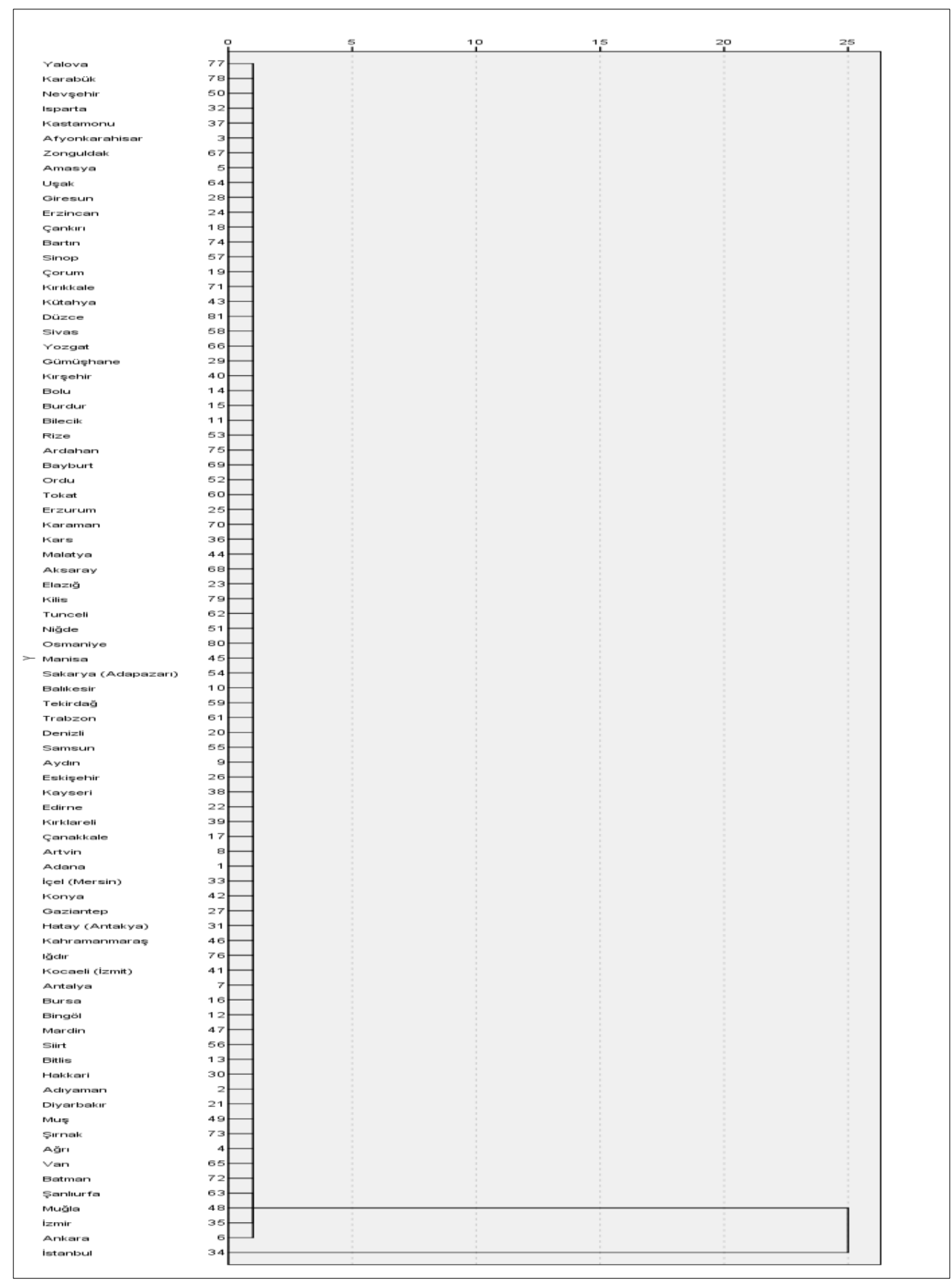

Şekil 4. Tek bağlantı tekniğine ait dendogram 


\subsubsection{Tam bağlantı tekniği analiz sonuçları}

Tam bağlantı tekniğine ilişkin dendogramın verildiği Şekil 5 incelendiğinde, ilk düzeyde Yalova, Karabük, Nevşehir, Isparta, Kastamonu, Bolu, Burdur, Rize, Bilecik, Afyonkarahisar, Zonguldak, Giresun, Amasya, Uşak, Erzincan, Sinop, Çankırı, Bartın, Ardahan, Tunceli, Kayseri, Samsun, Balıkesir, Tekirdağ, Trabzon, Samsun, Manisa, Sakarya (Adapazarı), Aydın, Eskişehir, Denizli, Kocaeli (İzmit), Adana, İçel (Mersin), Konya, Kütahya, Düzce, Sivas, Çorum, Kırıkkale, Yozgat, Gümüşhane, Kırşehir, Bayburt, Karaman, Ordu, Tokat, Erzurum, Kars, Edirne, Kırklareli, Çanakkale, Artvin ve Muğla illeri kendi aralarında kümelenmiş (birinci grup), Antalya, İzmir, Ankara ve Bursa illeri kendi aralarında (ikinci grup), Muş, Şırnak, Şanlıurfa, Ağrı, Van, Batman, Bingöl, Mardin ve Siirt illeri kendi aralarında (üçüncü grup), Bitlis, Hakkâri, Diyarbakır, Adıyaman, Kahramanmaraş, Iğdır, Niğde, Osmaniye, Malatya, Aksaray, Elazığ, Kilis, Gaziantep ve Hatay (Antakya) kendi aralarında kümelenmiştir (dördüncü grup). İkinci aşamada, birinci ile ikinci grup birleşerek beşinci grubu ve üçüncü ve dördüncü grup birleşerek altıncı grubu oluşturmuştur. Üçüncü aşamada, beşinci grup ile altıncı grup birleşerek yedinci grubu oluşturmuştur. Son aşamada ise, yedinci gruba İstanbul ili eklenmiştir.

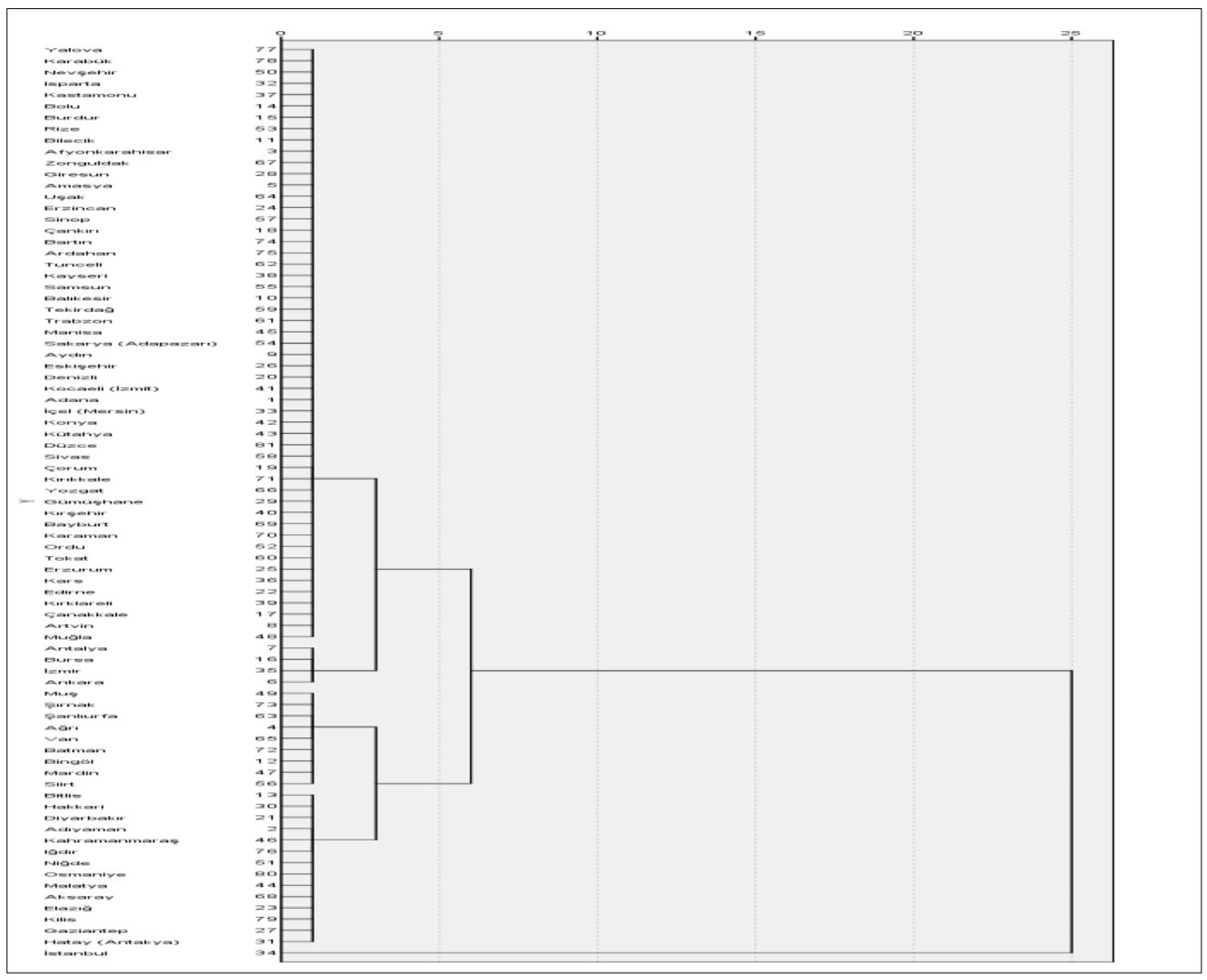

Şekil 5. Tam bağlantı tekniğine ait dendogram 


\subsubsection{Ward tekniği analiz sonuçları}

Temel bileşenler analizi ile elde edilen temel bileşenlere uygulanan Ward tekniği ile kümeleme analizi sonuçları Şekil 6'da verilmiştir. Dendogram incelendiğinde, Yalova, Karabük, Nevşehir, Isparta, Kastamonu, Tunceli, Bolu, Burdur, Bilecik, Rize, Kütahya, Düzce, Sivas, Çorum, Kırıkkale, Yozgat, Çankırı, Bartın, Ardahan, Afyonkarahisar, Zonguldak, Giresun, Amasya, Uşak, Erzincan, Sinop, Balıkesir, Tekirdağ, Trabzon, Aydın, Eskişehir, Denizli, Edirne, Kırklareli, Çanakkale, Artvin, Muğla, Antalya, Bursa, Kocaeli (İzmit), Manisa, Sakarya (Adapazarı), Kayseri, Samsun, Adana, İçel (Mersin), Konya illeri birleşerek A grubunu, Ankara ve İzmir B grubunu, Gümüşhane, Kırşehir, Bayburt, Karaman, Ordu, Tokat, Erzurum, Kars, Kahramanmaraş, Iğdır, Gaziantep, Hatay(Antakya), Niğde, Osmaniye, Malatya, Aksaray, Elazığ ve Kilis illeri birleşerek C grubunu, Ağrı, Van, Batman, Muş, Şırnak, Şanlıurfa, Bingöl, Mardin, Siirt Bitlis, Hakkâri, Diyarbakır ve Adıyaman illeri de birleşerek D grubunu oluşturmuştur. İkinci aşamada, A ve B grubu birleşerek E grubunu oluşturmuş. Üçüncü aşamada $\mathrm{E}$ grubuna $\mathrm{C}$ grubu dâhil olarak $\mathrm{F}$ grubunu oluşturmuş̧ur. Dördüncü aşamada, F grubuna $\mathrm{D}$ grubu dâhil olarak $\mathrm{G}$ grubunu oluşturmuştur. Son aşamada ise $\mathrm{G}$ grubuna İstanbul ili katılmıştır.

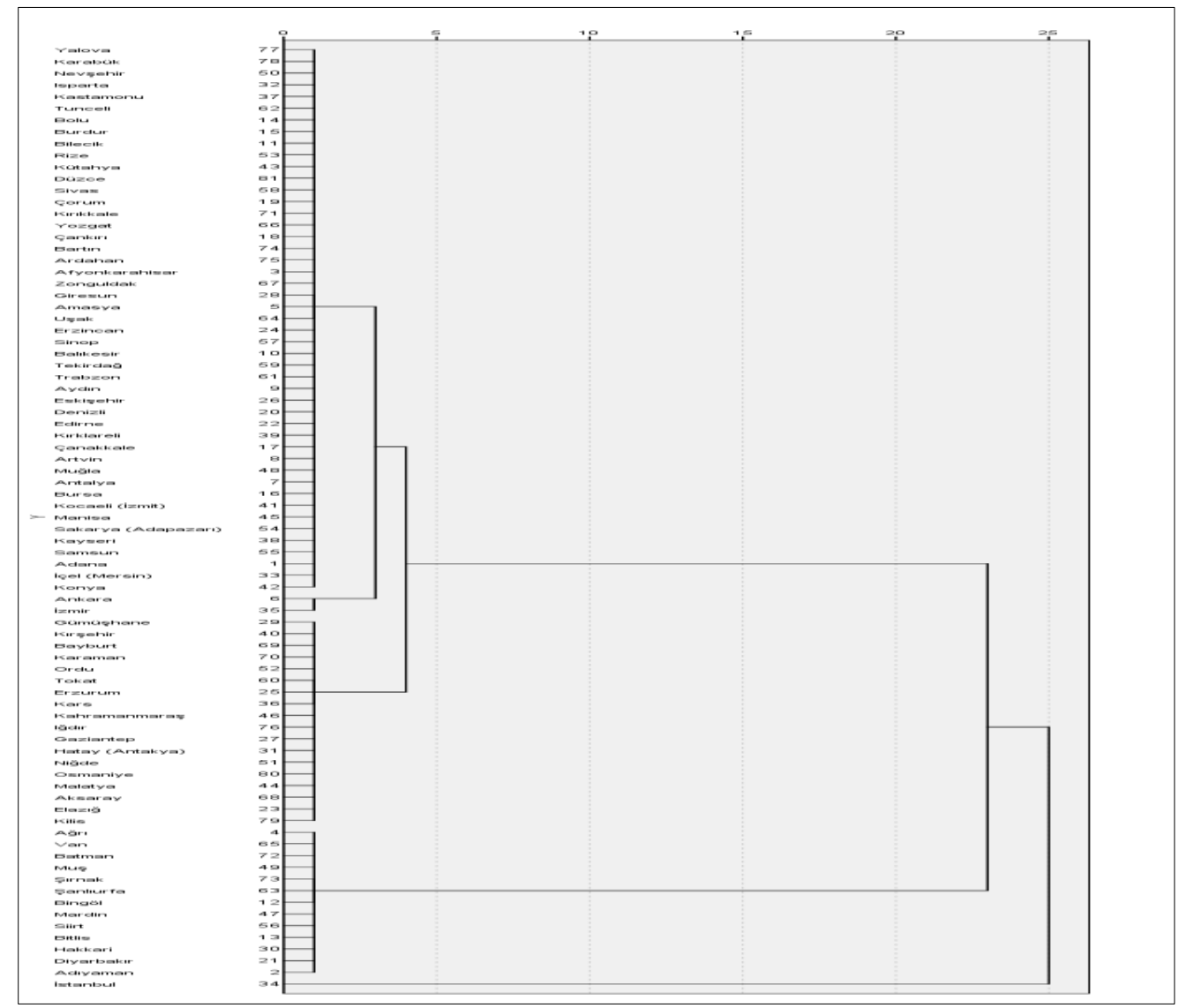




\subsubsection{K-ortalamalar tekniği analiz sonuçları}

Analizin bu aşamasında, ham verilere uygulanan kümeleme analizi k-ortalamalar tekniğinde olduğu gibi, küme sayısı sırasıyla 2 ve 3 olarak seçilmiştir. Elde edilen sonuçlar tablolar halinde verilmiştir.

Küme sayısı 2 olarak tercih edildiğinde elde edilen sonuçlar aşağı Tablo 9'da verilmiştir. Buna göre, İstanbul ilinin tek başına bir küme oluşturduğu, diğer 80 ilin ise birlikte diğer kümeyi oluşturdukları açıkça görülmektedir.

Tablo 9. Küme üyeliği

\begin{tabular}{|c|c|c|}
\hline $\begin{array}{l}\text { Küme } \\
\text { no }\end{array}$ & Küme elemanları & $\begin{array}{l}\text { Kümelerdeki } \\
\text { birim sayıs }\end{array}$ \\
\hline 1 & İstanbul & 1 \\
\hline 2 & $\begin{array}{l}\text { Adana, Diyarbakır, Konya, Tunceli, Adıyaman, Edirne, } \\
\text { Kütahya, Şanlıurfa, Afyonkarahisar, Elazı̆̆, Malatya, Uşak, } \\
\text { Ağrı, Erzincan, Manisa, Van, Amasya, Erzurum, } \\
\text { Kahramanmaraş, Yozgat, Ankara, Eskişehir, Mardin, } \\
\text { Zonguldak, Antalya, Gaziantep, Muğla, Aksaray, Artvin, } \\
\text { Giresun, Muş, Bayburt, Aydın, Gümüşhane, Nevşehir, } \\
\text { Karaman, Balıkesir, Hakkâri, Niğde, Kırıkkale, Bilecik, Hatay } \\
\text { (Antakya), Ordu, Batman, Bingöl, Isparta, Rize, Şırnak, Bitlis, } \\
\text { İçel (Mersin), Sakarya (Adapazarı), Bartın, Bolu, İzmir, } \\
\text { Samsun, Ardahan, Burdur, Kars, Siirt, Iğdır, Bursa, Kastamonu, } \\
\text { Sinop, Yalova, Çanakkale, Kayseri, Sivas, Karabük, Çankırı, } \\
\text { Kırklareli, Tekirdağ, Kilis, Çorum, Kırşehir, Tokat, Osmaniye, } \\
\text { Denizli, Kocaeli (İzmit), Trabzon, Düzce }\end{array}$ & 80 \\
\hline
\end{tabular}

Tablo 10'da verilen ANOVA sonuçları incelendiğinde, ikinci temel bileşenin p(sig) değerinin $\alpha=0.05$ 'ten büyük olduğu görülmüştür. Buna göre, ikinci temel bileşenin önemsiz olduğu söylenebilir. Bunun nedeni, söz konusu bileşenin, şube başına kişi sayısı ve ATM başına kişi sayısı değişkenlerinden oluşmasıdır. Ham verilere uygulanan k-ortalamalar tekniğinde de bu sonuca paralel bir sonuç ile karşılaşılmıştı.

Tablo 10. ANOVA sonuçları

\begin{tabular}{|l|l|l|}
\hline & F değeri & p değeri \\
\hline Birinci temel bileşen & 351.828 & .000 \\
\hline İkinci temel bileşen & 3.156 & .079 \\
\hline
\end{tabular}

Küme sayısı 3 olarak tercih edildiğinde elde edilen sonuçlar aşağı Tablo 11'de verilmiştir. Tablo incelendiğinde, İstanbul ilinin yine tek başına bir küme oluşturduğu, bunun yanı sıra 
birbirine yakın coğrafi bölgelerde bulunan Iğdır, Batman, Adıyaman, Bingöl, Diyarbakır, Muş, Şanlıurfa, Hakkâri, Şırnak, Ağrı, Bitlis, Mardin, Siirt ve Van illerinin birlikte bir küme oluşturdukları, geriye kalan 66 ilin ise birlikte kümelendikleri gözlemlenmektedir.

Tablo 11. Küme üyeliği

\begin{tabular}{|l|l|l|}
\hline $\begin{array}{l}\text { Küme } \\
\text { no }\end{array}$ & Küme elemanları & $\begin{array}{l}\text { Kümelerdeki } \\
\text { birim sayıs1 }\end{array}$ \\
\hline 1 & $\begin{array}{l}\text { Adana, Bursa, Giresun, Kocaeli (İzmit),Sakarya (Adapazarı), } \\
\text { Afyonkarahisar, Çanakkale, Gümüşane, Konya, Samsun, } \\
\text { Amasya, Çankırı, Hatay (Antakya),Kütahya, Sinop, Ankara, } \\
\text { Çorum, Isparta, Malatya, Sivas, Antalya, Denizli, İçel } \\
\text { (Mersin), Manisa, Tekirdağ, Artvin, Edirne, İzmir, } \\
\text { Kahramanmaras, Tokat, Aydın, Elazı̆g, Kars, Muğla, Trabzon, } \\
\text { Balıkesir, Erzincan, Kastamonu, Nevşehir, Tunceli, Bilecik, } \\
\text { Erzurum, Kayseri, Niğde, Uşak, Bolu, Eskişehir, Kırklareli, } \\
\text { Ordu, Yozgat, Burdur, Gaziantep, Kırşehir, Rize, Zonguldak, } \\
\text { Aksaray, Kırıkkale, Yalova, Osmaniye, Ardahan, Bayburt, } \\
\text { Bartın, Karabük, Düzce, Kilis, Karaman }\end{array}$ & 1 \\
\hline 2 & İstanbul & 14 \\
\hline 3 & $\begin{array}{l}\text { Iğdır, Batman, Adıyaman, Bingöl, Diyarbakır, Muş, Şanlıurfa, } \\
\text { Hakkâri, Şırnak, Ağrı, Bitlis, Mardin, Siirt, Van }\end{array}$ & 14 \\
\hline
\end{tabular}

Tablo 12. ANOVA sonuçları

\begin{tabular}{|l|l|l|}
\hline & F değeri & p değeri \\
\hline Birinci temel bileşen & 208.123 & .000 \\
\hline İkinci temel bileşen & 151.285 & .000 \\
\hline
\end{tabular}

Tablo 12'de görülen ANOVA sonuçlarına göre, analizde kullanılan iki temel bileșene ait $\mathrm{p}(\mathrm{sig})$ değerlerinin $\alpha=0.05$ anlamlılık düzeyinde anlamlı olduğu görülmektedir. Buna göre her iki temel bileşenin önemli olduğu söylenebilir.

\section{SONUÇ}

$\mathrm{Bu}$ çalışmanın temel amacı, iller arasındaki benzerlik ve farlılıkları bankacılık verileri 1şığında ortaya koymaktır. Bu amaca hizmetle ilk olarak temel bileşenler analizi yapılmıştır. Sonuçlara göre, toplam varyansın \%96.1'ini açıklayan iki temel bileşen elde edilmiştir. Şube sayısı, banka sayısı, toplam kredi, toplam mevduat, ATM sayısı, POS sayısı, üye işyeri sayısı ve çalışan sayısı değişkenleri birinci temel bileşende, ATM başına kişi sayısı ve şube başına kişi sayısı değişkenleri ise ikinci temel bileşende yer almıştır. 
Araştırmanın ikinci aşamasında, ham verilere kümeleme analizi uygulanmıştır. Analiz kapsamında uygulanan tek bağlantı tekniği, tam bağlantı tekniği ve Ward tekniğinde ortak nokta olarak İstanbul ilinin tek başına bir küme oluşturması ve oluşan kümelere son aşamada katılması görülebilir. Diğer iki tekniğe nazaran Ward tekniğinin daha sağlıklı sonuçlar verdiği söylenebilir. K-ortalamalar tekniğinde iki ve üç küme sayısı için analiz yapılmış, küme sayısı üç olarak seçildiğinde Ankara ve İzmir illerinin ayrı bir küme olduğu görülmüştür. Söz konusu iller ile ilgili önsel bilgiler değerlendirildiğinde bu durum şaşırtıcı değildir. Bu bulgulara ek olarak, şube başına kişi sayısı ve ATM başına kişi sayısı değişkenlerinin önemsiz olduğu tespit edilmiştir.

Temel bileşenler analizi ile elde edilen iki temel bileşene de, tek bağlantı tekniği, tam bağlantı tekniği, Ward tekniği ve k-ortalamalar teknikleri vasıtasıyla kümeleme analizi uygulanmıştır. Araştırmada bu aşamaya yer verilmesinin nedeni, temel bileşenler analizinin veri hazırlama süreçlerine katkısı olduğunun düşünülmesi ve akabinde yapılacak analizlerin hassasiyetini artıracağı beklentisidir. Yapılan uygulamada, bu beklenti ile paralel sonuçlar elde edilmiştir. Tek bağlantı tekniği sonuçları, 80 ilin birlikte kümelendiğini, bu kümeye ikinci aşamada İstanbul ilinin dâhil olduğunu göstermektedir. Tam bağlantı tekniği sonuçlarına bakıldığında 4 aşamalı bir kümeleme gerçekleştiği, ilk aşamada oluşan kümelerin ikisinde iller arasında coğrafi yakınlık olduğu görülmüştür. Bunun yanı sıra Türkiye'nin lokomotif illerinden Antalya, İzmir, Bursa ve Ankara illeri de bir küme oluşturmuştur. Ward tekniği ile yapılan analiz beş aşamalı olarak gerçekleşmiş, Ankara ve İzmir illerinin birlikte bir küme oluşturdukları gözlemlenmiştir. K-ortalamalar tekniği sonuçlarına göre; iki küme için İstanbul tek başına bir küme oluştururken diğer iller birlikte kümelenmiştir. Ek olarak, şube başına kişi sayısı ve ATM başına kişi sayısı değişkenlerinin oluşturduğu ikinci bileşen önemsiz olarak değerlendirilmiştir.

Küme sayısı üç olarak alındığında, 66 ilin birlikte, İstanbul ilinin tek başına ve 14 ilin birlikte kümelendikleri görülmektedir. Her iki bileşenin de önemli olduğu belirlenmiştir.

$\mathrm{Bu}$ çalışmada belirgin şekilde göze çarpan iki olgu söz konudur. Birincisi, kümeleme tekniği veya kullanılan verinin niteliği ne olursa olsun İstanbul ilinin diğer tüm illerden bankacılık değişkenleri bakımından oldukça farklı olmasıdır. İkincisi ise, temel bileşenler analizinin araştırmalarda kullanılacak diğer yöntemlerden önce uygulandığında çalışmanın hassasiyetini artırarak araştırmacılara yararlı olduğudur. Bunun yanı sıra, coğrafi olarak birbirine yakın illerin de birlikte kümelendikleri dikkat çekmektedir.

\section{KAYNAKÇA}

ABDEL-AZIZ, M. (1993). "Origin and domestication of the Dromedary (Arabic camel)", Paper presented at Proceedings of the 6th World Symposium on the History of Science of Arabs, Ras El-Kheimah, United Arab Emirates.

ANDERSON, T. W. (1958). An introduction to multivariate statistical analysis. Wiley, USA.

A. ÖZTÜRK, B., GÜRSAKAL, S. (2015). "Türkiye'deki İllerin Eğitim ve Sağlık Göstergelerine Göre Sinıflandırılması", Paradoks Ekonomi Sosyoloji ve Politika Dergisi, 11(2), 83-101.

BASİLEVSKİ, A. (1994). Statistical Factor Analysis and Related Methods: Theory and Applications. John Wiley \& Sons Inc., New York. 
CHATFIELD, C., COLLINS, A. J. (1980). Introduction to Multivariate Analysis. Chapman and Hall, London.

COOLEY, W., and LOHNES, P. R. (1971). Multivariate Data Analysis. John Wiley \& Sons Inc.

ÇAKMAK, Z., UZGÖREN, N., KEÇEK, G. (2005). "Kümeleme Analizi Teknikleri ile İllerin Kültürel Yapılarına Göre Sınıflandırılması ve Değişimlerinin İncelenmesi”, Dumlupınar Üniversitesi Sosyal Bilimler Dergisi. Sayı 12.

DİNÇER, B., ÖZASLAN, M., (2004). "İlçelerin Sosyoekonomik Gelişmişlik Sıralaması Araştırması". Devlet Planlama Teşkilatı, Ankara.

DINÇER, B., ÖZASLAN, M., KAVASOĞLU, T., (2003). “İllerin ve Bölgelerin SosyoEkonomik Gelişmişlik Sıralaması Araştırması”, Devlet Planlama Teşkilatı, Ankara.

ERSUNGUR, Ş. M., KIZILTAN, A., POLAT, Ö. (2007). “Türkiye'de Bölgelerin SosyoEkonomik Gelişmişlik Sıralaması: Temel Bileşenler Analizi”, Atatürk Üniversitesi İktisadi ve İdari Bilimler Dergisi, 21(2):55-66.

GIRSHICK, M. A. (1939). "On the Sampling Theory of Roots of Determinantal Equations”, The Annals of Mathematical Statistics, 10 (3):203-224.

GÜL, H. E., ÇEVİK, B. (2014). 2010 ve 2012 Verileriyle Türkiye'de İllerin Gelişmişlik Düzeyi Araştırması. Türkiye İş Bankası.

GÜNAL, M. (2001). Türk Bankacılık Sektörü’nün Sorunları ve Geleceği. Ankara Ticaret Odas1, Ankara.

HOTELlinG, H. (1933). "Analysis of a Complex of Statistical Variables into Principal Components", Journal of Educational Psychology, 24:417-520.

JACKSON, J.E. (1991). A user's guide to principle components. John Wiley \& Sons, New York.

JEFFERS, J.N.R. (1967). "Two Case Studies in the Application of Principal Component Analysis", Journal of the Royal Statistical Society. Series C (Applied Statistics), $16(3): 225-236$.

JOLLIFFE, I.T. (1986). Principal Component Analysis. Springer eBooks.

Kalkınma Bakanlığı (2013). İllerin ve Bölgelerin Sosyo-Ekonomik Gelişmişlik Sıralaması Araştırması (SEGE-2011). Bölgesel Gelişme ve Yapısal Uyum Genel Müdürlüğü, Ankara.

KART, R. B., KESER, İ. K. (2019). “Türkiye'deki İllerin Sosyo-Ekonomik Gelişmişlik Düzeylerinin Belirlenmesi ve Yerel Seçim Oy Dağılımlarının Karşılaştırılması”, Türkiye Sosyal Araştırmalar Dergisi, 23(1):25-52.

KAVASOĞLU, T. (2007). "Sosyo-Ekonomik Gelişmişlik Araştırması”, 2. Bölgesel Kalkınma ve Yönetişim Sempozyumu 25-26 Ekim 2007, İzmir.

KRZANOWSKI, W.J., (1987). "Selection of Variables to preserve Multivariate Data Structure, using Principal Components", Applied Statistics, No:1:22-33. 
MORRISON, D. F. (1967). Multivariate statistical methods. McGraw-Hill.

Orta Karadeniz Kalkınma Ajansı (2014). TR83 Bölgesi İlçeleri Sosyo-Ekonomik Gelişmişlik Endeksi.

ÖZGÜR, E. (2003). Çok Değişkenli İstatistiksel Analiz Yöntemleri ve Bir Uygulama, Gazi Üniversitesi Sosyal Bilimler Enstitüsü, Ankara.

RAO, C.R. (1964). The Use and Interpretation of Principal Component Analysis in Applied Research, Sankhya A.

ŞEN, H., ÇEMREK, F., ÖZAYDIN, Ö. (2006). "Türkiye'deki İllerin Sosyo-Ekonomik Gelişmişlik Düzeylerinin Belirlenmesi”, SÜ İ̈BF Sosyal ve Ekonomik Araştırmalar Dergisi, 11:155- 171.

TATLIDİL, H. (2002). Uygulamalı Çok Değişkenli İstatistiksel Analiz. Akademi Matbaası, Ankara.

TBB, Türkiye Bankalar Birliği, "Türkiye'de Bankacılık Sistemi Seçilmiş Göstergelerin İllere ve Bölgelere Göre Dağılımı",

https://www.tbb.org.tr/Content/Upload/istatistikiraporlar/ekler/1185/Bankacilik_Siste minin_Cografi_Dagilimi_2018.pdf, 06.02.2020.

TIMM, N.H. (2002). Applied Multivariate Analysis. Springer Verlag, New York.

YAMAN YILMAZ, C. ve ATAN, M. (2014). "Efficiency Ranking of Provinces in Turkey

Using NUTS-3”, International Journal of Research in Social Sciences, 6(10): 178-218.

YAYLALI, M., OKYAY, E., AKAN, Y. (2006). "Kişi Başına Düşen Gsyih Değerlerine Göre Türkiye'deki Coğrafi Bölgelerin ve GSYİH'yı Oluşturan Sektörlerin Kümelenmesi”, Atatürk Üniversitesi Sosyal Bilimler Enstitüsü Dergisi, 8 (2): 311-334. 